Adrián Valls Carbó ${ }^{1}$

Juan González del Castillo ${ }^{2-4}$

Oscar Miró ${ }^{5}$

Pedro Lopez-Ayala ${ }^{6}$

Sonia Jimenez ${ }^{5}$

Javier Jacob ${ }^{7}$

Carlos Bibiano ${ }^{8}$

F. Javier Martín-Sánchez ${ }^{2-4}$

\section{Increased severity in SARS-CoV-2 infection of minorities in Spain}

\author{
'Institute for Health Research of Hospital San Carlos, Madrid, Spain. \\ 2Emergency department, Hospital Clínico San Carlos, Madrid, Spain. \\ ${ }^{3}$ Faculty of de Medicine of Universidad Complutense de Madrid, Spain. \\ ${ }^{4}$ Institute for Health Research of Hospital San Carlos, Madrid, Spain. \\ ${ }^{5}$ Área de Urgencias, Hospital Clínic, Universitat de Barcelona, Barcelona, Spain. \\ ${ }^{6}$ Cardiovascular Research Institute Basel (CRIB) and Department of Cardiology, University Hospital Basel, University of \\ Basel, Basel, Switzerland \\ ${ }^{7}$ Emergency department. Hospital Universitario de Bellvitge, Barcelona, Spain. \\ ${ }^{8}$ Emergency department. Hospital Universitario Infanta Leonor, Madrid, Spain.
}

Article history

Received: 8 July 2021; Accepted: 21 September 2021; Published: 8 0ctober 2021

\section{ABSTRACT}

Introduction. With the global spread of COVID-19, studies in the US and UK have shown that certain communities have been strongly impacted by COVID-19 in terms of incidence and mortality. The objective of the study was to determine social determinants of health among COVID-19 patients hospitalized in the two major cities of Spain.

Material and methods. A multicenter retrospective case series study was performed collecting administrative databases of all COVID-19 patients $\geq 18$ years belonging to two centers in Madrid and two in Barcelona (Spain) collecting data from $1^{\text {st }}$ March to 15th April 2020. Variables obtained age, gender, birthplace and residence ZIP code. From ZIP code we obtained per capita income of the area. Predictors of the outcomes were explored through generalized linear mixed-effects models, using center as random effect.

Results. There were 5,235 patients included in the analysis. After multivariable analysis adjusted by age, sex, per capita income, population density, hospital experience, center and hospital saturation, patients born in Latin American countries were found to have an increase in ICU admission rates (OR $1.56[1.13-2.15], p<0.01)$ but no differences were found in the same model regarding mortality (OR 1.35 [0.95-1.92], $p=0.09$ ).

Conclusions. COVID-19 severity varies widely, not only depending on biological but also socio-economic factors. With the emerging evidence that this subset of population is at higher risk of poorer outcomes, targeted public health strategies and studies are needed.

Key words: COVID-19, mortality, sociodemographic impact

Correspondence:

Francisco Javier Martin Sanchez

Emergency Department. Hospital Clinico San Carlos.

Calle Profesor Martin-Lagos s/n, 28040 Madrid.

Phone Number: (34) 91.330.37.50

FAX Number: (34) 91.330.35.69

Email: fjjms@hotmail.com

\section{Mayor gravedad de la infección por SARS-CoV-2 en minorías en España}

Introducción. Con la propagación mundial de COVID-19, estudios de EE. UU y Reino Unido han demostrado que ciertas comunidades se han visto fuertemente afectadas por COVID-19 en términos de incidencia y mortalidad. El objetivo del estudio fue identificar los determinantes sociales que pudieran condicionar los resultados en salud en pacientes con COVID-19 hospitalizados en las dos principales ciudades de España.

Material y métodos. Se realizó un estudio multicéntrico retrospectivo de series de casos recogiendo las variables de las bases de datos administrativas de todos los pacientes COVID-19 $\geq 18$ años pertenecientes a dos centros de Madrid y dos de Barcelona (España) y evaluados de 1 de marzo al 15 de abril de 2020. Las variables obtenidas fueron la edad, sexo, lugar de nacimiento y código postal de residencia. A partir del código postal obtuvimos la renta per cápita de la zona. Los predictores de los resultados se exploraron a través de modelos lineales generalizados de efectos mixtos, utilizando el centro como efecto aleatorio.

Resultados. Se incluyeron 5.235 pacientes en el análisis. Después de un análisis multivariable ajustado por edad, sexo, ingreso per cápita, densidad de población, experiencia hospitalaria, centro y saturación hospitalaria, se encontró que los pacientes nacidos en paises de América Latina tenian un aumento en las tasas de ingreso en la UCI $(\mathrm{OR} 1,56[1,13-2,15], p<0,01)$, pero no se encontraron diferencias en el mismo modelo con respecto a la mortalidad (OR 1,35 [0,95-1,92], $p=0,09$ ).

Conclusiones. La gravedad de COVID-19 varía ampliamente, no solo según factores biológicos sino también socioeconómicos. Con la evidencia emergente de que este subconjunto de población tiene un mayor riesgo de peores resultados, se necesitan estrategias y estudios especificos de salud pública.

Palabras clave: COVID-19, mortalidad, impacto sociodemográfico. 


\section{INTRODUCTION}

Social determinants are important causes which can affect health $[1,2]$. This has been demonstrated to have a great importance in infectious diseases [3], where the interaction between the exposition to the microorganism and the health status are crucial to produce the disease.

Social inequality is the situation when resources are allocated unevenly, which generates patterns across socially defined categories of persons, such as ethnicity, gender or age. Social inequality determines a social vulnerability to the disease for each group, defined as risk exposure and capacity to recover for a community which is highly determined by income, work and access to healthcare system.

According to the UNDESA world social report, inequality has increased in most developed countries since 1990 [4]. In Spain, after the financial crisis of 2008, people at risk of poverty or social exclusion increased in two points from 2007 to 2019, while in the rest of Euro area remained stable [5].

With the global spread of COVID-19, studies in the US and UK have shown that certain communities have been strongly impacted by COVID-19 in terms of incidence and mortality [6]. While this relationship has been studied in Spain at aggregated level in Barcelona [7], no other social determinants of health apart from income have been studied in Spain. The objective of the study was to determine social determinants of health among COVID-19 patients hospitalized in the two major cities of Spain.

\section{MATERIAL AND METHODS}

A multicentered retrospective case series study was performed collecting administrative databases of all COVID-19 patients 318 years belonging to hospital area. Two centers in Madrid and two in Barcelona (Spain) participated in the study collecting data from $1^{\text {st }}$ March to 15th April 2020. All patients were followed until the $1^{\text {st }}$ June 2020 . We included all patients with a confirmed or high suspicion diagnosis for COVID-19.

From administrative databases we obtained age, gender, birthplace, and residence ZIP code. Patients who were born out of Spain were considered as immigrants and they were grouped into three categories: Latin American origin, Western countries different than Spain and other (which included patients from Africa, Asia and Oceania). From ZIP code we obtained per capita income of the area were each patient lived form the National Statistics Institute of Spanish Statistical Office (https://www.ine.es/en/index.htm). These geographical variables were obtained at census level and then merged into ZIP code via QGIS (QGIS Development Team (2020). QGIS Geographic Information System. Open Source Geospatial Foundation Project. http://qgis.osgeo.org). Hospital experience was defined as the number of COVID patients attended each day in the center during the study period. Hospital experience was calculated for each day and applied during the period were the patient was admitted. Saturation index was calculated as the total number of COVID patients who were admitted in the hospital divided by the total number of beds in each center and multiplied by the new COVID admitted in the hospital.

Comparisons among groups were made using t-Student for normal continuous variables. Wilcoxon signed-rank test for non-normal continuous variables and chi-square test was used for categorical variables. Follow-up started at the time of admission. Predictors of the outcomes were explored through generalized linear mixed-effects models, using center as random effect. Measures of association were expressed as odds ratio (OR), with a 95\% confidence interval (CI), adjusted for variables $p<0.10$ in the univariable analysis. Statistically significant differences were considered two-side $p$-value less than 0.05 or if OR 95\% Cl excluded 1. Data analysis was performed using $\mathrm{R}$ statistical software.

\section{RESULTS}

There were 5,235 patients included in the analysis. 44\% of the patients were female and median age was 68 (IOR 54-80). 3391 patients (65.8\%) were from Madrid and 1844 (35.2\%) were from Barcelona. Mortality and ICU admission rates were 15.9\% and $6.2 \%$ respectively (Table 1 ). Regarding birthplace $4288(82 \%)$ patients were born in occidental countries, 840 (16\%) were born in Latin America and 98 (1.8\%) in other regions. $20 \%$ of the patients of patients were immigrants, being $80 \%$ of them from Latin America. Latin American patients were younger (median age 50.0 [41.0;59.0], $p<0.01$ ) but no differences were found in sex. In univariable analysis it was shown that patients who were born in Latin America 1.58-fold (OR 1.58 [1.2-2.06], $p<0.01$ ) ICU admission rates than their Occidental born counterparts but a decrease in mortality rates (OR 0.27 [0.2-0.36], $p<0.01$ ).

After multivariable analysis adjusted by age, sex, per capita income, population density, hospital experience, center and hospital saturation, patients born in Latin American countries were found to have an increase in ICU admission rates (OR 1.56 [1.13-2.15], $p<0.01)$ but no differences were found in the same model regarding mortality (OR 1.35 [0.95-1.92], $p=0.09$ ).

\section{DISCUSSION}

Amongst hospitalized patients, we found significant increased odds of ICU admission for patients who were born in Latin-American countries. Although these cluster of patients showed a trend towards more mortality rates, this association was non statistically significant.

Our study is in line with the emerging evidence which suggest socially disfavored communities have poorer COVID-19 clinical outcomes. As ICU is a surrogate marker of critical illness, present study suggests that the disease in Latin American population may be more severe, which may not impact in mortality because this subset of population is younger.

Findings have to be interpreted in the context of Spanish social structure, where Latin American population constitutes 


\begin{tabular}{|c|c|c|c|c|c|}
\hline Table 1 & \multicolumn{5}{|c|}{ Characteristics of the population included in the study. } \\
\hline Demographic patient data & t data & $\begin{array}{c}\text { Total } \\
(\mathrm{N}=5,235)\end{array}$ & $\begin{array}{c}\text { Madrid } \\
(\mathrm{N}=3,391)\end{array}$ & $\begin{array}{l}\text { Barcelona } \\
(\mathrm{N}=1,844)\end{array}$ & $\mathrm{p}$ value \\
\hline \multicolumn{2}{|c|}{ Age (years); median (IOR) } & $68.0(54.0-80.0)$ & $69.0[54.0-81.0]$ & $67.0[54.0-77.0]$ & $<0.01$ \\
\hline \multicolumn{2}{|c|}{ Gender female; $n(\%)$} & $2,308(44.1)$ & $1,505(44.4)$ & $803(43.5)$ & 0.581 \\
\hline \multicolumn{2}{|c|}{ Foreigners; $n(\%)$} & $1,044(20.0)$ & $828(24.5)$ & $216(11.7)$ & $<0.01$ \\
\hline \multicolumn{3}{|c|}{ Place of birth; $n(\%)$} & & & $<0.01$ \\
\hline \multicolumn{2}{|l|}{ Spain } & $4,182(80.0)$ & $2,556(75.5)$ & $1,626(88.3)$ & \\
\hline \multicolumn{2}{|c|}{ Latin America countries } & $840(16.1)$ & $686(20.3)$ & $154(8.4)$ & \\
\hline \multicolumn{2}{|c|}{ Western countries except Spain } & $106(2.0)$ & $74(2.2)$ & $32(1.7)$ & \\
\hline \multicolumn{2}{|c|}{ Arabic countries } & $45(0.9)$ & $34(1.0)$ & $11(0.6)$ & \\
\hline \multicolumn{2}{|c|}{ Asian countries } & $39(0.7)$ & $24(0.7)$ & $15(0.8)$ & \\
\hline \multicolumn{2}{|c|}{ Sub-Saharan African countries } & $14(0.3)$ & $10(0.3)$ & $4(0.2)$ & \\
\hline \multicolumn{2}{|l|}{ Origin; $n(\%)$} & & & & $<0.01$ \\
\hline \multicolumn{2}{|l|}{ Occidental } & $4,288(82.1)$ & $2,630(77.7)$ & $1,658(90.0)$ & \\
\hline \multicolumn{2}{|c|}{ Latin America } & $840(16.1)$ & $686(20.3)$ & $154(8.4)$ & \\
\hline \multicolumn{2}{|l|}{ Other } & $98(1.9)$ & $68(2.0)$ & $30(1.6)$ & \\
\hline \multicolumn{6}{|c|}{ Data related to ZIP code area where patients live } \\
\hline \multicolumn{2}{|c|}{ Average per capita income of ZIP code areas in $€ /$ person; median (IOR) } & $11,797(8932.5-14268)$ & $10,673.50[8,909-11,950]$ & $12,451[11,213-14,861]$ & $<0.01$ \\
\hline \multicolumn{2}{|c|}{ Percentile of average per capita income of ZIP code area; median (IOR) } & $0.71(0.17-0.93)$ & $0.49[0.17,0.74]$ & $0.80[0.60,0.95]$ & $<0.01$ \\
\hline \multicolumn{2}{|c|}{ Population density (people/km²); median (IOR) } & $1,242.75(414.5-2,364.37)$ & $1,035.26[773.2-1,645.4]$ & $1,496.12[107.4-3,742.4]$ & \\
\hline \multicolumn{2}{|c|}{ Percentile of population density of ZIP code area median (IOR) } & $0.71(0.17-0.93)$ & $0.49[0.17-0.74]$ & $0.8[0.6-0.95]$ & \\
\hline \multicolumn{6}{|c|}{ Hospital care data } \\
\hline \multicolumn{2}{|c|}{ Hospital Experience Index; median (IOR) } & $1,305(772-1801.5)$ & $1,638.50[1,047.00-2,055.50]$ & $826.00[607.00-1,221.00]$ & $<0.01$ \\
\hline \multicolumn{2}{|c|}{ Emergency Department Saturation Index; median (IQR) } & $37.56(16.15-67.3)$ & 54.54 [37.56- 86.15] & $16.15[7.13-23.30]$ & $<0.01$ \\
\hline \multicolumn{6}{|c|}{ Primary outcomes } \\
\hline \multicolumn{2}{|c|}{ Critical care admission; $n(\%)$} & $323(6.2)$ & $165(4.9)$ & $158(8.6)$ & $<0.01$ \\
\hline \multicolumn{2}{|c|}{ In-hospital mortality; $\mathrm{n}(\%)$} & $832(15.9)$ & $575(17.0)$ & $257(13.9)$ & $<0.01$ \\
\hline
\end{tabular}

the main immigrant and minoritized community. While other studies have tried to explain outcome disparities in different ethnical communities due to biological differences, modern scholarship regards race as a social construct which is just a weak proxy for genetic diversity [8]. Although outcomes in our study were adjusted by income, several determinants such as education, employment and cultural differences in access to healthcare remain uncontrolled to affirm such differences in severity are attributable to biological factors. Therefore more studies in this direction are needed to provide more evidence.

COVID-19 severity varies widely $[9,10]$, not only depending on biological but also socio-economic factors. With the emerging evidence that this subset of population is at higher risk of poorer outcomes, targeted public health strategies and studies are needed.

\section{FUNDING}

None to declare

\section{CONFLICTS OF INTEREST}

The authors declare that they have no conflict of interest

\section{REFERENCES}

1. Preda A, Voigt K. The social determinants of health: why should we care? Am J Bioeth. 2015;15(3):25-36. doi:10.1080/15265161.2014. 998374

2. Krieger $N$, Chen JT, Waterman PD, Soobader M-J, Subramanian S $V$, Carson R. Geocoding and Monitoring of US Socioeconomic Ine- 
qualities in Mortality and Cancer Incidence: Does the Choice of Area-based Measure and Geographic Level Matter?: The Public Health Disparities Geocoding Project. Am J Epidemiol. 2002;156(5):471482. doi:10.1093/aje/kwf068

3. Semenza JC, Giesecke J. Intervening to reduce inequalities in infections in Europe. Am J Public Health. 2008;98(5):787-792. doi:10.2105/AJPH.2007.120329

4. UN (2020), World Social Report 2020: Inequality in a Rapidly Changing World, UN, New York,

5. Union E. Eurostat.

6. Patel $A$, Abdulaal $A$, Ariyanayagam $D$, et al. Investigating the association between ethnicity and health outcomes in SARS$\mathrm{CoV}-2$ in a London secondary care population. PLOS One. 2020;15(10):e0240960. doi:10.1371/journal.pone.0240960

7. Baena-Díez JM, Barroso M, Cordeiro-Coelho SI, Díaz JL, Grau M. Impact of COVID-19 outbreak by income: hitting hardest the most deprived. J Public Health (Oxf). Published online August 2020. doi:10.1093/pubmed/fdaa136

8. Yudell $M$, Roberts $D_{1}$, DeSalle $R$, Tishkoff $S$. Taking race out of human genetics. Science (80- ). 2016;351(6273):564 LP - 565. doi:10.1126/science.aac4951

9. Martín-Sánchez FJ, Del Toro E, Cardassay E, et al. Clinical presentation and outcome across age categories among patients with COVID-19 admitted to a Spanish Emergency Department. Eur Geriatr Med. Published online July 2020:1-13. doi:10.1007/s41999-02000359-2

10. Gil-Rodrigo A, Miró Ò, Piñera P, et al. Analysis of clinical characteristics and outcomes in patients with COVID-19 based on a series of 1000 patients treated in Spanish emergency departments. Emergencias Rev la Soc Esp Med Emergencias. 2020;32(4):233-241. 